\title{
Transplantation in Diabetic Kidney Failure Patients: Modalities, Outcomes, and Clinical Management
}

\author{
Fu L. Luan and Millie Samaniego \\ Internal Medicine, Division of Nephrology, University of Michigan, Ann Arbor, Michigan
}

\begin{abstract}
Diabetes mellitus (DM) is a common and devastating disease, affecting up to 19.3 million Americans. It is the leading cause of chronic kidney disease (CKD) and end-stage renal disease (ESRD) in the United States. Diabetic patients with ESRD have a high incidence of cardiovascular disease and death. For those kidney transplant patients with no history of DM prior to transplantation, the development of new onset diabetes after transplantation (NODAT) also poses a serious threat to both graft and patient survival. Kidney transplantation is the best renal replacement option for diabetic ESRD and has the potential to halt the progression of cardiovascular diseases. Early referral for transplant evaluation is essential for pre-emptive or early kidney transplantation in this cohort of patients. In type 1 DM patients with ESRD, simultaneous pancreas and kidney transplantation (SPK) should be encouraged; and in patients

facing prolonged waiting time for SPK transplantation but with an available living donor, living donor kidney transplantation followed by pancreas after kidney transplantation (PAK) is a suitable alternative. Islet transplantation in type 1 diabetics is deemed experimental by Medicare, and easy access to this modality remains restricted to qualified patients enrolled in clinical trials or with private insurance. The optimal management of kidney transplant patients with pre-existent DM or NODAT involves a multi-pronged approach consisting of pharmacological and nonpharmacological intervention to address all potential cardiovascular risk factors such as glycemic and lipid control, blood pressure control, weight loss, and smoking cessation. Finally, re-transplantation should be recommended in suitable kidney transplant patients when the kidney allograft demonstrates continuous and progressive decline in function.
\end{abstract}

Diabetes mellitus (DM) affects an estimated 19.3 million American adults with a prevalence of 9.3\% (1). Its incidence continues to increase, particularly in the developing countries, and it is estimated that by 2025 , 300 million people worldwide will be affected by this condition (2). DM is a strong risk factor for cardiovascular disease, chronic kidney disease (CKD), and premature death in the adult population (3-5). In fact, diabetic kidney disease occurs in $20-40 \%$ of patients with DM and is the leading cause of CKD and end-stage renal disease (ESRD) in the United States, accounting for nearly $45 \%$ of the dialysis patient population (6-8). In patients with both DM and CKD, the incidence of various cardiovascular complications and death is much higher than either condition alone $(5,8)$.

Most diabetic patients will die of cardiovascular events prior to developing CKD or progressing to ESRD. For those who develop diabetic nephropathy, as evidenced by the appearance of microalbuminuria and decline in glomerular filtration rate (GFR), with eventual progression to ESRD, kidney transplantation

Address correspondence to: Fu L. Luan, MD, 3914 Taubman Center, Box 0364, 1500 East Medical Center Drive, Ann Arbor, Ml 48109-0364, e-mail: fluan@med.umich.edu.

Seminars in Dialysis-Vol 23, No 2 (March-April) 2010 pp. 198-205

DOl: 10.1111/j.1525-139X.2010.00708.x

(C) 2010 Wiley Periodicals, Inc. is the renal replacement therapy of choice. In type 1 diabetics with ESRD, simultaneous pancreas and kidney (SPK), or pancreas after kidney (PAK) transplantation are feasible options for qualified individuals whereas islet transplantation remains experimental at this time $(9,10)$.

In patients without previous history of DM, any form of solid organ transplantation constitutes a risk factor for the development of new onset diabetes after transplantation (NODAT) (11). The development of NODAT portends an additional cardiovascular risk to transplant patients in general and to kidney transplant patients in particular $(12,13)$.

Diabetes mellitus, present prior to or developing after kidney transplantation, represents a unique challenge to kidney transplant patients. In this review, we will focus our discussion on kidney transplantation as the treatment for diabetic ESRD patients, the effects of new onset diabetes after kidney transplantation, and on pancreas transplantation in type $1 \mathrm{DM}$ patients.

\section{Progression of Diabetic Chronic Kidney Disease and the Timing of Kidney Transplantation}

Historically, $20-40 \%$ of diabetic patients develop diabetic nephropathy over a period of 25 years from the onset of disease, and 5-15\% progress to ESRD (14-16). 
Besides genetic risk factors, hypertension, and hyperglycemia are the two most important risk factors for the development and subsequent progression of diabetic CKD (17-22). Aggressive lowering of blood pressure to $130 / 80 \mathrm{mmHg}$ or less with the use of an angiotensinconverting enzyme inhibitor (ACEI) and/or angiotensin II receptor blocker (ARB) and strict glucose control, targeting $\mathrm{HbA}_{1 \mathrm{c}}$ to near normal $(<7 \%)$, appear to slow the progression of diabetic CKD $(20,21,23,24)$. Nevertheless, a portion of patients will experience progressive decline in renal function and subsequent ESRD (22). Ultimately, these patients will require lifesustaining, long-term renal replacement therapy, either in the form of dialysis or kidney transplantation.

As in any other patient with CKD, the preparation for renal replacement therapy of diabetic patients requires focused patient education and timely referral to the nephrologist, vascular surgeon, and transplant specialist. Delayed referral for specialized care is common and results in poor pre-ESRD care, whereas timely referral improves the likelihood of pre-emptive or early (i.e., within the first 2 years of dialysis therapy) kidney transplantation (25-27). The choice of dialysis or kidney transplantation depends on many factors, including timely recognition of continued decline in renal function, resource availability, and patient co-morbidity. In the United States, the overwhelming majority of incident diabetic patients with ESRD will be initiated on renal replacement therapy in the form of hemodialysis, a phenomenon that is not exclusive to diabetic patients (8).

Diabetic CKD patients experience a high incidence of cardiovascular events and death that is further increased after they begin dialysis therapy $(5,8,28)$. Kidney transplantation provides a better alternative when compared with dialysis as far as overall and cardiovascular mortality is concerned, a benefit that is particularly enjoyed by both type 1 and 2 diabetics. In a landmark study, Wolfe et al., examined at a national level the mortality among ESRD patients wait-listed for a kidney transplant when compared with that of ESRD patients who received a deceased donor kidney transplant (29). Kidney transplantation was associated with a significantly lower risk of death 18 months after transplantation (relative risk, $0.32,95 \%$ CI $0.30,0.35$ ) with survival benefit clearly demonstrable 244 days after transplantation. The projected increase in life expectancy by transplantation was 10 years on average across all kidney transplant patients; of note, this survival advantage was particularly strong in diabetic ESRD patients, mainly because of their poorer survival on dialysis. Other investigators from different parts of the world have shown similar findings supporting the reproducibility of Wolfe's findings $(30,31)$. A reduction in cardiovascular risk is the main reason for the survival advantage conferred by kidney transplantation $(28,32)$.

The optimal timing for kidney transplantation in a diabetic patient with advanced CKD and/or ESRD is largely a matter of availability of a donor kidney. Avoiding dialysis or at least limiting its duration to no more than 180 days is associated with better post-transplant outcome and should be strongly recommended (33-35). Mange et al. showed that living donor kidney transplant recipients without previous history of dialysis treatment had a $52 \%$ reduction in risk of graft failure within the first year after transplantation, when compared with those who were on dialysis at the time of transplantation $(p=0.002)$, with further reduction of risk during subsequent years following transplantation $(82 \%$ in second year and $86 \%$ thereafter, respectively, $p=0.001$ ) (33). Mange further observed that longer duration of dialysis treatment prior to transplantation was associated with increased risk for acute rejection within the first 6 months of transplantation.

In a subsequent study, Kasiske et al. demonstrated similar findings in patients receiving a deceased donor kidney transplant (25\% risk reduction in graft failure for pre-emptive kidney transplant recipients when compared with those patients who had initiated dialysis prior to kidney transplantation) (36). More importantly, according to those investigators, the pre-emptive kidney transplantation resulted in improvement of patient survival $(26 \%$ and $31 \%$ risk reduction in patient death for deceased and living donor kidney transplant recipients, respectively). More recently, Becker et al. investigated the benefit of pre-emptive kidney transplantation in type 1 and 2 diabetic ESRD population (37). The benefit of pre-emptive transplantation in this patient population regarding patient and graft survival was only observed after living donor kidney or SPK transplantation.

Thus, it is important to emphasize the advantage of pre-emptive living donor kidney transplantation in diabetic ESRD patients. Since diabetic patients come to receive medical attention much earlier than patients with nondiabetic CKD, early screening for kidney disease should be part of routine care for diabetic patients which consists of measurement of both microalbuminuria and serum creatinine (38). Once kidney disease is detected, periodic and ongoing monitoring of GFR becomes one of the most important aspects of patient care with regard to slowing the progression to ESRD and preparing for pre-emptive living donor kidney transplantation $(27,39)$.

As more than 86,000 patients with ESRD are currently waiting for a kidney transplant and a little more than 13,000 kidney transplants are performed annually in the United States, the waiting time for a deceased donor kidney transplant has remained stagnant across the nation with a median time of three or more years (40). The avoidance of dialysis or shortening the length of dialysis is only possible if patients with CKD are referred to nephrologists and/or transplant centers when estimated GFR (eGFR) is around $30 \mathrm{ml} / \mathrm{min}$, with the goal of listing the patient as soon as the eGFR declines to an average value of $20 \mathrm{ml} / \mathrm{min}$ or less, the UNOS requirement for placement in the renal transplant waiting list in the United States.

Under most circumstances, however, pre-emptive kidney transplantation is more likely to occur with a living donor as there is no waiting time involved. Discussion of the benefits of pre-emptive living donor kidney transplantation, and encouraging appropriate recipient candidates to search for potential living donors should be considered as part of a transplant evaluation process. 


\section{Management of Diabetic ESRD Patients after Kidney Transplantation}

Although kidney transplantation is the superior treatment modality for patients with ESRD, the survival of kidney transplant patients remains inferior to that of the general population in part because of the accumulated cardiovascular burden and CKD vintage $(41,42)$. The same cardiovascular risk factors that are relevant in the general population remain relevant in kidney transplant patients $(43,44)$. In particular, the presence of DM and cardiovascular disease prior to kidney transplantation represents the most important predictors for cardiovascular events and all-cause mortality after kidney transplantation (45-47). In a cohort of 933 first-time kidney transplant patients, Cosio et al., showed that when compared with nondiabetic kidney transplant patients, kidney transplant patients with history of DM had a significantly higher incidence of post-transplant cardiovascular events ( $25 \%$ vs. $7.4 \%, p<0.0001)$, cardiovascular mortality $(12 \%$ vs. $1.1 \%, p<0.0001)$ and all-cause mortality (19.3\% vs. $6.1 \%, p<0.0001)(45)$. Aalten et al. from the Netherlands showed similar findings in that pretransplant diabetic nephropathy was associated with a more than three times higher risk of having post-transplant cardiovascular events (46). It appeared that the high cardiovascular burden in DM patients before kidney transplantation was the driving force for persistence of elevated cardiovascular events observed after kidney transplantation.

It is important to point out that the incidence of cardiovascular events and death is highest in the first 3 months after kidney transplantation $(29,44-46,48)$. This has been attributed to the fact that prolonged CKD and ESRD markedly increase cardiovascular risk, and multiple other comorbid conditions $(43,49)$. Furthermore, despite the improvement in cardiovascular risks observed in patients following kidney transplantation, newer transplant-related risk factors such as immunosuppressive drugs, and inflammation due to opportunistic infection, particularly cytomegalovirus infection, perpetuate the high cardiovascular risk status of the kidney transplant patient population $(48,50)$. The fact that the majority of kidney transplant patients will have a mild to moderate degree of CKD makes matters worse $(51,52)$.

The role of immunosuppressive drugs on promoting cardiovascular risks has been well-documented (53). For example, the use of steroids, calcineurin inhibitors (CNIs) such as cyclosporine and tacrolimus, and more recently sirolimus can all contribute to and exacerbate hypercholesterolemia and hypertriglyceridemia that are already highly prevalent in kidney transplant patients (54-56). Hypertension, another conventional cardiovascular risk factor, is present in over $75 \%$ of kidney transplant patients, and its control is influenced negatively by steroids and CNIs $(50,57)$. Both hyperlipidemia and hypertension are associated with reduced renal allograft survival in addition to increased risk for cardiovascular disease $(58,59)$. For each $10 \mathrm{mmHg}$ incremental rise in SBP, the risk for death and graft failure increases by $18 \%$ and $17 \%$, respectively (59). In diabetic ESRD patients, glycemic control tends to get worse and difficult to manage shortly after kidney transplantation. Insulin requirement may increase and oral hypoglycemic agents may fail, mostly because of increased insulin resistance and impaired insulin secretion associated with the use of steroids and CNIs (60-62).

At the present time, any improvement in cardiovascular disease risk in diabetic kidney transplant patients hinges on the appropriated management of conventional cardiovascular risk factors. The use of statins, possibly early after kidney transplantation, to lower LDL cholesterol has been shown to reduce cardiac death, nonfatal myocardial infarction, proteinuria, and interstitial fibrosis in the kidney allograft recipient (63-67). As most statins and CNIs are metabolized through the same cytochrome P450 system (CP3A4), attention should be paid to an increased frequency of rhabdomyolysis because of accumulation of statins in plasma with the use of CNIs (68). The reduction of LDL cholesterol to less than $100 \mathrm{mg} / \mathrm{dl}$ is generally recommended, but for diabetic kidney transplant recipients with history of preexistent cardiovascular disease, a goal of LDL cholesterol of less than $70 \mathrm{mg} / \mathrm{dl}$ may be optimal $(56,69)$.

Blood pressure control had to target a goal of $\leq 130 / 80 \mathrm{mmHg}$ or $\leq 125 / 70 \mathrm{mmHg}$ in the setting of established proteinuria (70). The choice of various antihypertensive agents often depends on the type of patients and the timing following kidney transplantation (71). Calcium channel blockers (CCB) are widely used as first-line therapy, particularly early post-transplantation, to counteract the vasoconstrictive effects of CNIs (57). While the use of ACEI and ARB is becoming more widespread their renal protective role, beyond decreasing proteinuria, has not been universally documented in kidney transplant patients (72-74). Glycemic control should target $\mathrm{HbA}_{1 \mathrm{c}}$ of less than $7 \%$ and fasting plasma glucose of $90-130 \mathrm{mg} / \mathrm{dl}(7,75)$. The use of various oral hypoglycemic agents and/or insulin depends on pre-transplant DM history. Referral to an endocrinologist is highly recommended.

It is important to emphasize that, in addition to the aforementioned pharmacological interventions to improve cardiovascular risk factors, lifestyle modification including dietary precautions, increasing physical exercise, weight loss, and smoking cessation should be strongly recommended, although the adherence to lifestyle modification is notoriously poor (76-81).

\section{New Onset Diabetes after Kidney Transplantation}

Patients with no history of DM prior to the transplantation are at risk of developing NODAT. Kasiske et al. studied 11,659 Medicare beneficiaries of first kidney transplant recipients and found a cumulative incidence of NODAT of $9.1 \%, 16 \%$, and $24 \%$ at 3,12 , and 24 months after transplantation, respectively (11). Woodard et al. compared the incidence of NODAT between transplanted kidney patients and wait-listed nondiabetic ESRD kidney transplant candidates. They found that the cumulative incidence of NODAT more 
than doubled when compared with pretransplantation level (82). In both studies, the risk of NODAT was highest in the first year after transplantation, although the risk remains elevated through the late post-transplant period (83). The development of NODAT increases the risk for cardiovascular events and the mortality following kidney transplantation (Fig. 1A,B) $(12,13)$.

In addition to overt NODAT, kidney transplant recipients are at a greater risk for insulin resistance with a significantly high proportion of them having impaired glucose tolerance (IGT) and/or impaired fasting glucose (IFG), compared to the general population (84-86). IFG, a potential precursor of overt DM, occurs in about $26 \%$ of the US adult population and is associated with other cardiovascular risk factors $(1,87,88)$. It has been suggested that IFG is a surrogate marker of insulin resistance that is ultimately responsible for the adverse cardiovascular outcome (89).

Besides traditional risk factors involved in pretransplant diabetes mellitus, the use of immunosuppressive drugs plays a major role in the genesis of NODAT and IGT $(11,90)$. Steroids cause insulin resistance, CNIs impair secretion of insulin, and sirolimus decreases
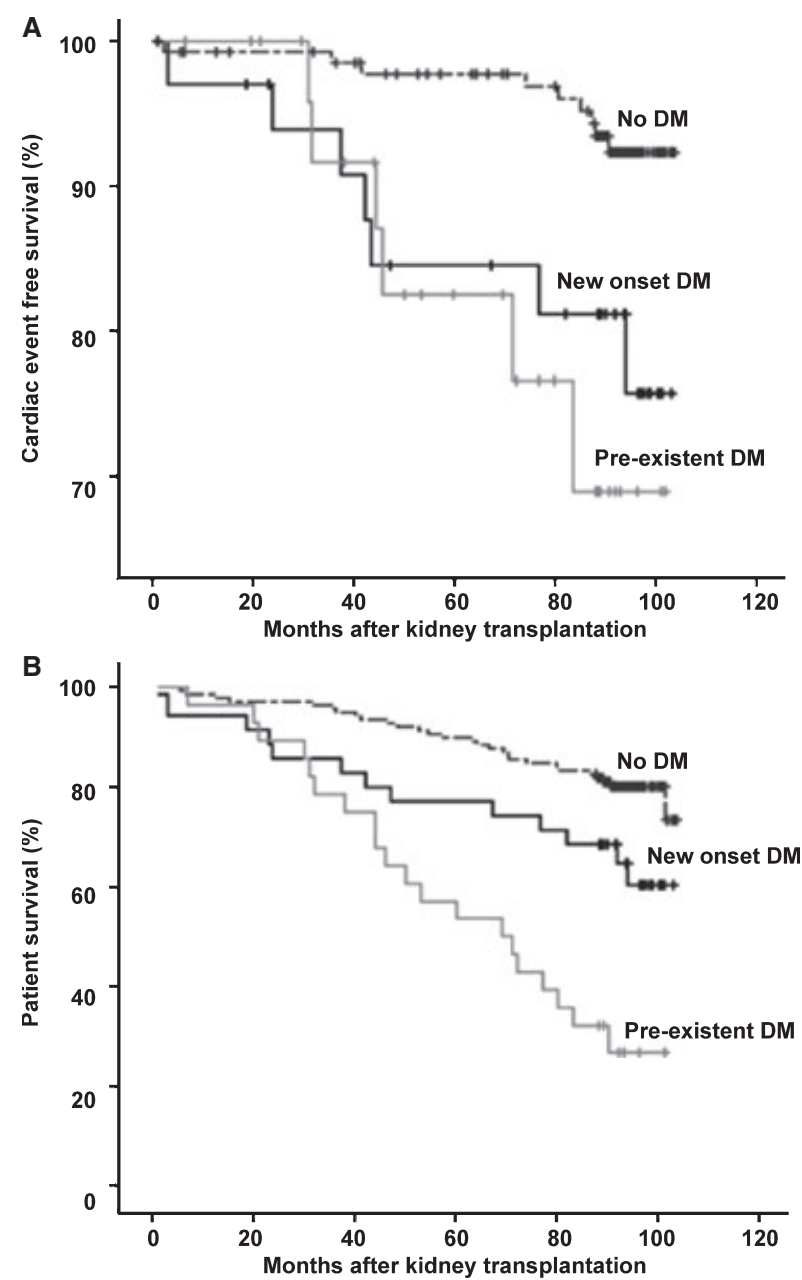

FIG. 1. Kaplan-Meier estimates of cardiac event-free survival (A) and patient survival (B) in renal transplant recipients according to the presence or absence of pre-existent diabetes, new onset diabetes. Adapted from Hjelmesaeth et al. with permission (13). insulin sensitivity $(60-62,91)$. More recently, the use of steroid-free immunosuppression appears to have decreased the risk of NODAT (Fig. 2) (92-95). Nevertheless, modification of immunosuppression purely for the purpose of decreasing the risk of NODAT has to be balanced with the need of preventing graft rejection, as acute rejection may increase in steroid-free immunosuppression and has a stronger deleterious effect on graft survival $(93,96)$.

The early detection of impaired glucose metabolism and NODAT in kidney transplant patients has been advocated by many investigators $(86,97)$. Whether early detection leads to long-term graft and patient survival remains to be determined. Therapeutic intervention for patients who developed NODAT should include lifestyle modification, the use of oral hypoglycemic agents and/or insulin (75).

\section{Pancreas Transplantation in Diabetic ESRD Patients}

For type 1 and, rarely, type 2 diabetic patients, pancreas transplantation is also an option (98). Pancreas transplantation can be performed either at the same time of kidney transplantation (SPK transplantation) or after kidney transplantation (PAK transplantation). Pancreas transplantation can also be performed in type $1 \mathrm{DM}$ patients without evidence of nephropathy (pancreas transplantation alone), and islet transplantation can be carried out before or after kidney transplantation. These last two subjects are beyond the scope of this review and will not be discussed further.

In a registry data analysis, Ojo et al. compared patient survival between comparable type 1 diabetic ESRD patients who received SPK, and living or deceased donor kidney transplant alone. Patients with SPK had better survival when compared with deceased but not to living donor kidney transplant alone recipients (99). When those patients who received SPK or kidney alone using contralateral kidneys from the same deceased donor were compared, the survival advantage of SPK was no longer observed (100).

In studies where SPK transplantation has resulted in long-term improvement of patient survival, pancreas

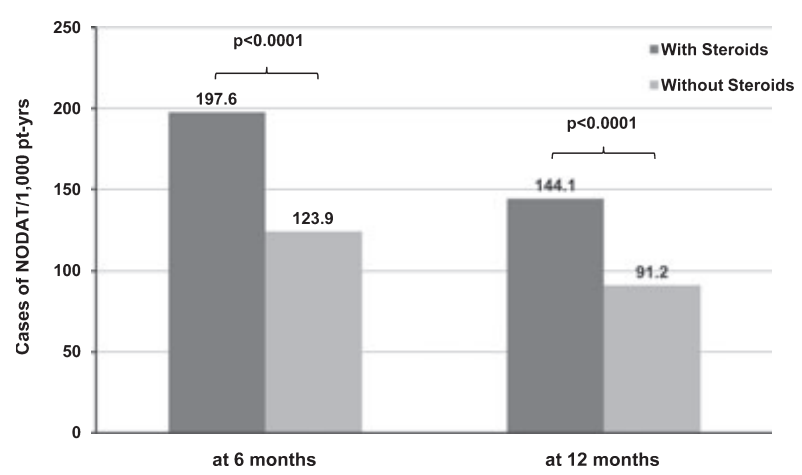

FIG. 2. Cumulative incidence of new onset diabetes in a national cohort of kidney transplant recipients discharged on steroid-free immunosuppressive regimens (96). 
allograft survival played an important role $(101,102)$. In a recent study of more than 3000 SPK patients followed for a maximum of 18 years, Morath et al., showed superior patient survival for SPK patients when compared with living donor kidney transplant alone patients beyond the 10th year after transplantation (hazard ratio $0.55, p=0.005)(103)$. For patients who undergo PAK transplantation, the patient survival may be worse than those patients treated with conventional therapy, although one recent study showed otherwise $(104,105)$.

On the contrary, successful pancreas transplantation does improve metabolic control and the cardiovascular risk profile, and can potentially reverse diabetic end organ damage as demonstrated by many investigators (106-110). In addition, the improvement in quality of life (QOL) will play an important role in determining the utility of pancreas transplantation. Several QOL studies have shown that when pancreas transplantation was successful, patients reported improvement in QOL when compared with type 1 diabetics who received a kidney transplant alone $(111,112)$.

It is therefore safe to say that pancreas transplantation is a suitable option for type 1 diabetic ESRD patients. SPK transplantation should be discussed as one of the treatment options for type 1 diabetic ESRD patients, and equally encouraged as living donor kidney transplantation to qualified candidates.

\section{Management of Failing Graft and Retransplantation in Diabetic Patients}

Kidney graft failure represents a serious challenge to the transplant physicians as the process itself incurs an additional risk for patient survival. Rao et al. showed that the mortality risk increased significantly after kidney graft failure when compared with first-time kidney transplant candidates on the waiting list (hazard ratio $1.78, p<0.0001)$, and mortality was greater among patients with DM than those without DM (hazard ratio 1.93 vs. 1.69) (113). Similar findings were present in type 1 DM kidney transplant patients who lost kidney graft and returned on dialysis (114).

These data suggest that it is advisable for diabetic kidney transplant patients with failing kidney grafts to be evaluated for retransplantation before they actually return to dialysis. Nonetheless, retransplantation does represent a significant challenge because of the increased risk of subsequent graft failure that has been documented $(115,116)$. Additional studies are needed to define the best timing for a repeat transplantation, and the optimal management of diabetic patients undergoing repeat kidney transplantation.

\section{Conclusion}

Although kidney transplantation represents the best opportunity for diabetic patients with ESRD, improving their survival after kidney transplantation remains a substantial challenge. As diabetic patients, on dialysis or after kidney transplantation, continue to carry a huge cardiovascular burden, only approaches that address multiple risks will have the potential to make an impact on outcomes. Neither improvement in glycemic control, improvement in hypertension and hyperlipidemia, prevention of weight gain, nor smoking cessation alone is likely going to change the outcome, but the combination of all of them will potentially help our patients to achieve a longer survival.

Since clinical trials assessing the cardiovascular benefit of particular therapeutic interventions in kidney transplant patients are scarce to nonexistent, future research in this area will be critical to guiding our approach. Until then, physicians must extrapolate the best evidence practice obtained from the general population to the diabetic kidney transplant population.

\section{Acknowledgment}

The authors thank Ms. Diana Kenney for careful review of manuscript.

\section{Disclosures}

Fu L. Luan, M.D., no conflict of interest.

Millie Samaniego, M.D., no conflict of interest.

\section{References}

1. Cowie CC, Rust KF, Byrd-Holt DD, Eberhardt MS, Flegal KM, Engelgau MM, Saydah SH, Williams DE, Geiss LS, Gregg EW: Prevalence of diabetes and impaired fasting glucose in adults in the U.S. population: National Health And Nutrition Examination Survey 1999-2002. Diabetes Care 29:1263-1268, 2006

2. King H, Aubert RE, Herman WH: Global burden of diabetes, 19952025: prevalence, numerical estimates, and projections. Diabetes Care 21:1414-1431, 1998

3. Nichols GA, Gullion CM, Koro CE, Ephross SA, Brown JB: The incidence of congestive heart failure in type 2 diabetes: an update. Diabetes Care 27:1879-1884, 2004

4. MacDonald MR, Petrie MC, Hawkins NM, Petrie JR, Fisher M, McKelvie R, Aguilar D, Krum H, McMurray JJ: Diabetes, left ventricular systolic dysfunction, and chronic heart failure. Eur Heart $J$ 29:1224-1240, 2008

5. Foley RN, Murray AM, Li S, Herzog CA, McBean AM, Eggers PW, Collins AJ: Chronic kidney disease and the risk for cardiovascular disease, renal replacement, and death in the United States Medicare population, 1998 to 1999. J Am Soc Nephrol 16:489-495, 2005

6. Coresh J, Selvin E, Stevens LA, Manzi J, Kusek JW, Eggers P, Van Lente F, Levey AS: Prevalence of chronic kidney disease in the United States. JAMA 298:2038-2047, 2007

7. KDOQI Clinical Practice Guidelines and Clinical Practice Recommendations for Diabetes and Chronic Kidney Disease. Am J Kidney Dis 49:S12-S154, 2007

8. National Institute of Health (NIH), (NIDDK) NIoDaDaKD: 2008 Annual Data Report: Atlas of End-Stage Renal Disease in the United States. In, National Institute of Health (NIH), National Institute of Diabetes and Digestive and Kidney Diseases (NIDDK), 2008

9. Dean PG, Kudva YC, Stegall MD: Long-term benefits of pancreas transplantation. Curr Opin Organ Transplant 13:85-90, 2008

10. Shapiro AM, Ricordi C, Hering BJ, Auchincloss H, Lindblad R, Robertson RP, Secchi A, Brendel MD, Berney T, Brennan DC, Cagliero E, Alejandro R, Ryan EA, DiMercurio B, Morel P, Polonsky KS, Reems JA, Bretzel RG, Bertuzzi F, Froud T, Kandaswamy R, Sutherland DE, Eisenbarth G, Segal M, Preiksaitis J, Korbutt GS, Barton FB, Viviano L, Seyfert-Margolis V, Bluestone J, Lakey JR: International trial of the Edmonton protocol for islet transplantation. N Engl J Med 355:1318-1330, 2006

11. Kasiske BL, Snyder JJ, Gilbertson D, Matas AJ: Diabetes mellitus after kidney transplantation in the United States. Am J Transplant 3:178-185, 2003 
12. Cosio FG, Pesavento TE, Kim S, Osei K, Henry M, Ferguson RM: Patient survival after renal transplantation: IV. Impact of post-transplant diabetes. Kidney Int 62:1440-1446, 2002

13. Hjelmesaeth J, Hartmann A, Leivestad T, Holdaas H, Sagedal S, Olstad M, Jenssen T: The impact of early-diagnosed new-onset posttransplantation diabetes mellitus on survival and major cardiac events. Kidney Int 69:588-595, 2006

14. Andersen AR, Christiansen JS, Andersen JK, Kreiner S, Deckert T: Diabetic nephropathy in Type 1 (insulin-dependent) diabetes: an epidemiological study. Diabetologia 25:496-501, 1983

15. Ballard DJ, Humphrey LL, Melton LJ III, Frohnert PP, Chu PC, O'Fallon WM, Palumbo PJ: Epidemiology of persistent proteinuria in type II diabetes mellitus. Population-based study in Rochester, Minnesota. Diabetes 37:405-412, 1988

16. Hovind P, Tarnow L, Rossing P, Jensen BR, Graae M, Torp I, Binder $\mathrm{C}$, Parving HH: Predictors for the development of microalbuminuria and macroalbuminuria in patients with type 1 diabetes: inception cohort study. BMJ 328:1105-1108, 2004

17. Seaquist ER, Goetz FC, Rich S, Barbosa J: Familial clustering of diabetic kidney disease. Evidence for genetic susceptibility to diabetic nephropathy. N Engl J Med 320:1161-1165, 1989

18. Nelson RG, Bennett PH, Beck GJ, Tan M, Knowler WC, Mitch WE, Hirschman GH, Myers BD: Development and progression of renal disease in Pima Indians with non-insulin-dependent diabetes mellitus. Diabetic Renal Disease Study Group. N Engl J Med 335:1636-1642, 1996

19. Poulsen PL, Hansen KW, Mogensen CE: Ambulatory blood pressure in the transition from normo- to microalbuminuria. A longitudinal study in IDDM patients. Diabetes 43:1248-1253, 1994

20. The effect of intensive treatment of diabetes on the development and progression of long-term complications in insulin-dependent diabetes mellitus. The Diabetes Control and Complications Trial Research Group. N Engl J Med 329:977-986, 1993

21. Intensive blood-glucose control with sulphonylureas or insulin compared with conventional treatment and risk of complications in patients with type 2 diabetes (UKPDS 33). UK Prospective Diabetes Study (UKPDS) Group. Lancet 352:837-853, 1998

22. Rossing K, Christensen PK, Hovind P, Tarnow L, Rossing P, Parving $\mathrm{HH}$ : Progression of nephropathy in type 2 diabetic patients. Kidney Int 66:1596-1605, 2004

23. Lewis EJ, Hunsicker LG, Bain RP, Rohde RD: The effect of angiotensin-converting-enzyme inhibition on diabetic nephropathy. The Collaborative Study Group. N Engl J Med 329:1456-1462, 1993

24. Brenner BM, Cooper ME, de Zeeuw D, Keane WF, Mitch WE, Parving HH, Remuzzi G, Snapinn SM, Zhang Z, Shahinfar S: Effects of losartan on renal and cardiovascular outcomes in patients with type 2 diabetes and nephropathy. $N$ Engl J Med 345:861-869, 2001

25. Obrador GT, Ruthazer R, Arora P, Kausz AT, Pereira BJ: Prevalence of and factors associated with suboptimal care before initiation of dialysis in the United States. J Am Soc Nephrol 10:1793-1800, 1999

26. Arora P, Obrador GT, Ruthazer R, Kausz AT, Meyer KB, Jenuleson CS, Pereira BJ: Prevalence, predictors, and consequences of late nephrology referral at a tertiary care center. $J$ Am Soc Nephrol 10:1281-1286, 1999

27. Weng FL, Mange KC: A comparison of persons who present for preemptive and nonpreemptive kidney transplantation. Am J Kidney Dis 42:1050-1057, 2003

28. Muntner P, He J, Hamm L, Loria C, Whelton PK: Renal insufficiency and subsequent death resulting from cardiovascular disease in the United States. J Am Soc Nephrol 13:745-753, 2002

29. Wolfe RA, Ashby VB, Milford EL, Ojo AO, Ettenger RE, Agodoa LY, Held PJ, Port FK: Comparison of mortality in all patients on dialysis, patients on dialysis awaiting transplantation, and recipients of a first cadaveric transplant. $N$ Engl J Med 341:1725-1730, 1999

30. Schnuelle P, Lorenz D, Trede M, Van Der Woude FJ: Impact of renal cadaveric transplantation on survival in end-stage renal failure: evidence for reduced mortality risk compared with hemodialysis during long-term follow-up. J Am Soc Nephrol 9:2135-2141, 1998

31. McDonald SP, Russ GR: Survival of recipients of cadaveric kidney transplants compared with those receiving dialysis treatment in Australia and New Zealand, 1991-2001. Nephrol Dial Transplant 17:22122219,2002

32. Kasiske BL, Maclean JR, Snyder JJ: Acute myocardial infarction and kidney transplantation. J Am Soc Nephrol 17:900-907, 2006

33. Mange KC, Joffe MM, Feldman HI: Effect of the use or nonuse of long-term dialysis on the subsequent survival of renal transplants from living donors. N Engl J Med 344:726-731, 2001

34. Meier-Kriesche HU, Kaplan B: Waiting time on dialysis as the strongest modifiable risk factor for renal transplant outcomes: a paired donor kidney analysis. Transplantation 74:1377-1381, 2002

35. Goldfarb-Rumyantzev A, Hurdle JF, Scandling J, Wang Z, Baird B, Barenbaum L, Cheung AK: Duration of end-stage renal disease and kidney transplant outcome. Nephrol Dial Transplant 20:167-175, 2005
36. Kasiske BL, Snyder JJ, Matas AJ, Ellison MD, Gill JS, Kausz AT: Preemptive kidney transplantation: the advantage and the advantaged. J Am Soc Nephrol 13:1358-1364, 2002

37. Becker BN, Rush SH, Dykstra DM, Becker YT, Port FK: Preemptive transplantation for patients with diabetes-related kidney disease. Arch Intern Med 166:44-48, 2006

38. Standards of medical care in diabetes-2007. Diabetes Care 30(Suppl. 1):S4-S41, 2007

39. Taal MW, Brenner BM: Predicting initiation and progression of chronic kidney disease: developing renal risk scores. Kidney Int 70:1694-1705, 2006

40. Organ Procurement and Transplantation Network/Human Resources and Service Administration. Available at http://optn.transplant. hrsa.gov/latestData, 2009

41. Foley RN, Parfrey PS, Sarnak MJ: Clinical epidemiology of cardiovascular disease in chronic renal disease. Am J Kidney Dis 32:S112-S119, 1998

42. Levey AS, Beto JA, Coronado BE, Eknoyan G, Foley RN, Kasiske BL, Klag MJ, Mailloux LU, Manske CL, Meyer KB, Parfrey PS, Pfeffer MA, Wenger NK, Wilson PW, Wright Jr JT: Controlling the epidemic of cardiovascular disease in chronic renal disease: what do we know? What do we need to learn? Where do we go from here? National Kidney Foundation Task Force on Cardiovascular Disease. Am J Kidney Dis 32:853-906, 1998

43. Kasiske BL, Chakkera HA, Roel J: Explained and unexplained ischemic heart disease risk after renal transplantation. J Am Soc Nephrol 11:1735-1743, 2000

44. Lentine KL, Brennan DC, Schnitzler MA: Incidence and predictors of myocardial infarction after kidney transplantation. J Am Soc Nephrol $16: 496-506,2005$

45. Cosio FG, Hickson LJ, Griffin MD, Stegall MD, Kudva Y: Patient survival and cardiovascular risk after kidney transplantation: the challenge of diabetes. Am J Transplant 8:593-599, 2008

46. Aalten J, Hoogeveen EK, Roodnat JI, Weimar W, Borm GF, de Fijter JW, Hoitsma AJ: Associations between pre-kidney-transplant risk factors and post-transplant cardiovascular events and death. Transpl Int 21:985-991, 2008

47. Kiberd B, Panek R: Cardiovascular outcomes in the outpatient kidney transplant clinic: the Framingham risk score revisited. Clin J Am Soc Nephrol 3:822-828, 2008

48. Meier-Kriesche HU, Schold JD, Srinivas TR, Reed A, Kaplan B: Kidney transplantation halts cardiovascular disease progression in patients with end-stage renal disease. Am J Transplant 4:1662-1668, 2004

49. Tonelli M, Wiebe N, Culleton B, House A, Rabbat C, Fok M, McAlister F, Garg AX: Chronic kidney disease and mortality risk: a systematic review. J Am Soc Nephrol 17:2034-2047, 2006

50. Ojo AO: Cardiovascular complications after renal transplantation and their prevention. Transplantation 82:603-611, 2006

51. Fellstrom B, Jardine AG, Soveri I, Cole E, Neumayer HH, Maes B, Gimpelewicz C, Holdaas H: Renal dysfunction is a strong and independent risk factor for mortality and cardiovascular complications in renal transplantation. Am J Transplant 5:1986-1991, 2005

52. Meier-Kriesche HU, Baliga R, Kaplan B: Decreased renal function is a strong risk factor for cardiovascular death after renal transplantation. Transplantation 75:1291-1295, 2003

53. Miller LW: Cardiovascular toxicities of immunosuppressive agents. Am J Transplant 2:807-818, 2002

54. Vincenti F, Jensik SC, Filo RS, Miller J, Pirsch J: A long-term comparison of tacrolimus (FK506) and cyclosporine in kidney transplantation: evidence for improved allograft survival at five years. Transplantation 73:775-782, 2002

55. Chueh SC, Kahan BD: Dyslipidemia in renal transplant recipients treated with a sirolimus and cyclosporine-based immunosuppressive regimen: incidence, risk factors, progression, and prognosis. Transplantation 76:375-382, 2003

56. Kasiske B, Cosio FG, Beto J, Bolton K, Chavers BM, Grimm R Jr, Levin A, Masri B, Parekh R, Wanner C, Wheeler DC, Wilson PW: Clinical practice guidelines for managing dyslipidemias in kidney transplant patients: a report from the Managing Dyslipidemias in Chronic Kidney Disease Work Group of the National Kidney Foundation Kidney Disease Outcomes Quality Initiative. Am J Transplant 4(Suppl. 7): $13-53,2004$

57. Kasiske BL, Anjum S, Shah R, Skogen J, Kandaswamy C, Danielson B, O'Shaughnessy EA, Dahl DC, Silkensen JR, Sahadevan M, Snyder JJ: Hypertension after kidney transplantation. Am J Kidney Dis 43:1071-1081, 2004

58. Wissing KM, Abramowicz D, Broeders N, Vereerstraeten P: Hypercholesterolemia is associated with increased kidney graft loss caused by chronic rejection in male patients with previous acute rejection. Transplantation 70:464-472, 2000

59. Opelz G, Wujciak T, Ritz E: Association of chronic kidney graft failure with recipient blood pressure. Collaborative Transplant Study. Kidney Int 53:217-222, 1998 
60. Hjelmesaeth J, Hartmann A, Kofstad J, Stenstrom J, Leivestad T, Egeland T, Fauchald P: Glucose intolerance after renal transplantation depends upon prednisolone dose and recipient age. Transplantation 64:979-983, 1997

61. Duijnhoven EM, Boots JM, Christiaans MH, Wolffenbuttel BH, Van Hooff JP: Influence of tacrolimus on glucose metabolism before and after renal transplantation: a prospective study. J Am Soc Nephrol 12:583-588, 2001

62. Menegazzo LA, Ursich MJ, Fukui RT, Rocha DM, Silva ME, Ianhez LE, Sabbaga E, Wajchenberg BL: Mechanism of the diabetogenic action of cyclosporin A. Horm Metab Res 30: 663-667, 1998

63. Holdaas H, Fellstrom B, Jardine AG, Holme I, Nyberg G, Fauchald P, Gronhagen-Riska C, Madsen S, Neumayer HH, Cole E, Maes B, Ambuhl P, Olsson AG, Hartmann A, Solbu DO, Pedersen TR: Effect of fluvastatin on cardiac outcomes in renal transplant recipients: a multicentre, randomised, placebo-controlled trial. Lancet 361:2024-2031, 2003

64. Holdaas H, Fellstrom B, Cole E, Nyberg G, Olsson AG, Pedersen TR, Madsen S, Gronhagen-Riska C, Neumayer HH, Maes B, Ambuhl P, Hartmann A, Staffler B, Jardine AG: Long-term cardiac outcomes in renal transplant recipients receiving fluvastatin: the ALERT extension study. Am J Transplant 5:2929-2936, 2005

65. Holdaas H, Fellstrom B, Jardine AG, Nyberg G, Gronhagen-Riska C, Madsen S, Neumayer HH, Cole E, Maes B, Ambuhl P, Logan JO, Staffler B, Gimpelewicz C: Beneficial effect of early initiation of lipidlowering therapy following renal transplantation. Nephrol Dial Transplant 20:974-980, 2005

66. Sandhu S, Wiebe N, Fried LF, Tonelli M.: Statins for improving renal outcomes: a meta-analysis. J Am Soc Nephrol 17:2006-2016, 2006

67. Masterson R, Hewitson T, Leikis M, Walker R, Cohney S, Becker G: Impact of statin treatment on 1-year functional and histologic renal allograft outcome. Transplantation 80:332-338, 2005

68. Maltz HC, Balog DL, Cheigh JS: Rhabdomyolysis associated with concomitant use of atorvastatin and cyclosporine. Ann Pharmacother $33: 1176-1179,1999$

69. Grundy SM, Cleeman JI, Merz CN, Brewer HB Jr, Clark LT, Hunninghake DB, Pasternak RC, Smith SC Jr, Stone NJ: Implications of recent clinical trials for the National Cholesterol Education Program Adult Treatment Panel III guidelines. Circulation 110:227-239, 2004

70. K/DOQI clinical practice guidelines on hypertension and antihypertensive agents in chronic kidney disease. Am J Kidney Dis 43:S1-S290, 2004

71. Shirali AC, Bia MJ: Management of cardiovascular disease in renal transplant recipients. Clin J Am Soc Nephrol 3:491-504, 2008

72. Hiremath S, Fergusson D, Doucette S, Mulay AV, Knoll GA: Renin angiotensin system blockade in kidney transplantation: a systematic review of the evidence. Am J Transplant 7:2350-2360, 2007

73. Heinze G, Mitterbauer C, Regele H, Kramar R, Winkelmayer WC, Curhan GC, Oberbauer R: Angiotensin-converting enzyme inhibitor or angiotensin II type 1 receptor antagonist therapy is associated with prolonged patient and graft survival after renal transplantation. $J A m$ Soc Nephrol 17:889-899, 2006

74. Opelz G, Zeier M, Laux G, Morath C, Dohler B: No improvement of patient or graft survival in transplant recipients treated with angiotensin-converting enzyme inhibitors or angiotensin II type 1 receptor blockers: a collaborative transplant study report. J Am Soc Nephrol $17: 3257-3262,2006$

75. Davidson J, Wilkinson A, Dantal J, Dotta F, Haller H, Hernandez D, Kasiske BL, Kiberd B, Krentz A, Legendre C, Marchetti P, Markell M, van der Woude FJ, Wheeler DC: New-onset diabetes after transplantation: 2003 International consensus guidelines. Proceedings of an international expert panel meeting. Barcelona, Spain, 19 February 2003. Transplantation 75:SS3-SS24, 2003

76. Third Report of the National Cholesterol Education Program (NCEP) Expert Panel on Detection, Evaluation, and Treatment of High Blood Cholesterol in Adults (Adult Treatment Panel III) final report. Circulation 106:3143-3421, 2002

77. Appel LJ, Moore TJ, Obarzanek E, Vollmer WM, Svetkey LP, Sacks FM, Bray GA, Vogt TM, Cutler JA, Windhauser MM, Lin PH, Karanja N: A clinical trial of the effects of dietary patterns on blood pressure. DASH Collaborative Research Group. N Engl J Med 336:11171124,1997

78. van den Ham EC, Kooman JP, Christiaans MH, van Hooff JP: Relation between steroid dose, body composition and physical activity in renal transplant patients. Transplantation 69:1591-1598, 2000

79. Kasiske BL, Klinger D: Cigarette smoking in renal transplant recipients. J Am Soc Nephrol 11:753-759, 2000

80. Sigal RJ, Kenny GP, Boule NG, Wells GA, Prud'homme D, Fortier M, Reid RD, Tulloch H, Coyle D, Phillips P, Jennings A, Jaffey J: Effects of aerobic training, resistance training, or both on glycemic control in type 2 diabetes: a randomized trial. Ann Intern Med 147:357-369, 2007

81. Mitka M: DASH dietary plan could benefit many, but few hypertensive patients follow it. JAMA 298:164-165, 2007
82. Woodward RS, Schnitzler MA, Baty J, Lowell JA, Lopez-Rocafort L, Haider S, Woodworth TG, Brennan DC: Incidence and cost of new onset diabetes mellitus among U.S. wait-listed and transplanted renal allograft recipients. Am J Transplant 3:590-598, 2003

83. Luan FL, Zhang H, Schaubel DE, Miles CD, Cibrik D, Norman S, Ojo AO: Comparative risk of impaired glucose metabolism associated with cyclosporine versus tacrolimus in the late posttransplant period. Am J Transplant 8:1871-1877, 2008

84. Ekstrand AV, Eriksson JG, Gronhagen-Riska C, Ahonen PJ, Groop LC: Insulin resistance and insulin deficiency in the pathogenesis of posttransplantation diabetes in man. Transplantation 53:563-569, 1992

85. Midtvedt K, Hartmann A, Hjelmesaeth J, Lund K, Bjerkely BL: Insulin resistance is a common denominator of post-transplant diabetes mellitus and impaired glucose tolerance in renal transplant recipients. Nephrol Dial Transplant 13:427-431, 1998

86. Sharif A, Moore RH, Baboolal K: The use of oral glucose tolerance tests to risk stratify for new-onset diabetes after transplantation: an underdiagnosed phenomenon. Transplantation 82:1667-1672, 2006

87. Unwin N, Shaw J, Zimmet P, Alberti KG: Impaired glucose tolerance and impaired fasting glycaemia: the current status on definition and intervention. Diabet Med 19:708-723, 2002

88. Donahue RP, Orchard TJ: Diabetes mellitus and macrovascular complications. An epidemiological perspective. Diabetes Care 15:11411155, 1992

89. Facchini FS, Hua N, Abbasi F, Reaven GM: Insulin resistance as a predictor of age-related diseases. J Clin Endocrinol Metab 86:3574 3578, 2001

90. Romagnoli J, Citterio F, Nanni G, Favi E, Tondolo V, Spagnoletti G, Salerno MP, Castagneto M: Incidence of posttransplant diabetes mellitus in kidney transplant recipients immunosuppressed with sirolimus in combination with cyclosporine. Transplant Proc 38:1034 1036, 2006

91. Teutonico A, Schena PF, Di Paolo S: Glucose metabolism in renal transplant recipients: effect of calcineurin inhibitor withdrawal and conversion to sirolimus. J Am Soc Nephrol 16:3128-3135, 2005

92. Vincenti F, Schena FP, Paraskevas S, Hauser IA, Walker RG, Grinyo $\mathrm{J}$ : A randomized, multicenter study of steroid avoidance, early steroid withdrawal or standard steroid therapy in kidney transplant recipients. Am J Transplant 8:307-316, 2008

93. Woodle ES, First MR, Pirsch J, Shihab F, Gaber AO, Van Veldhuisen P: A prospective, randomized, double-blind, placebo-controlled multicenter trial comparing early (7 day) corticosteroid cessation versus long-term, low-dose corticosteroid therapy. Ann Surg 248:564-577, 2008

94. Luan FL, Steffick DE, Ojo AO: Steroid-free maintenance immunosuppression in kidney transplantation: is it time to consider it as a standard therapy? Kidney Int 6:825-830, 2009

95. Luan FL, Steffick D., Ojo AO: New onset diabetes mellitus in kidney transplant recipients receiving de novo steroid free maintenance immunosuppression. Am J Transplant 9(Suppl.):208, 2009

96. Matas AJ, Gillingham KJ, Humar A, Ibrahim HN, Payne WD, Gruessner RW, Dunn TB, Sutherland DE, Najarian JS, Kandaswamy R: Posttransplant diabetes mellitus and acute rejection: impact on kidney transplant outcome. Transplantation 85:338-343, 2008

97. Kuypers DR, Claes K, Bammens B, Evenepoel P, Vanrenterghem Y: Early clinical assessment of glucose metabolism in renal allograft recipients: diagnosis and prediction of post-transplant diabetes mellitus (PTDM). Nephrol Dial Transplant 23:2033-2042, 2008

98. White SA, Shaw JA, Sutherland DE: Pancreas transplantation. Lancet 373:1808-1817, 2009

99. Ojo AO, Meier-Kriesche HU, Hanson JA, Leichtman A, Magee JC, Cibrik D, Wolfe RA, Port FK, Agodoa L, Kaufman DB, Kaplan B: The impact of simultaneous pancreas-kidney transplantation on longterm patient survival. Transplantation 71:82-90, 2001

100. Waki K, Terasaki PI: Kidney graft and patient survival with and without a simultaneous pancreas utilizing contralateral kidneys from the same donor. Diabetes Care 29:1670-1672, 2006

101. Reddy KS, Stablein D, Taranto S, Stratta RJ, Johnston TD, Waid TH, McKeown JW, Lucas BA, Ranjan D: Long-term survival following simultaneous kidney-pancreas transplantation versus kidney transplantation alone in patients with type 1 diabetes mellitus and renal failure. Am J Kidney Dis 41:464-470, 2003

102. Salvalaggio PR, Dzebisashvili N, Pinsky B, Schnitzler MA, Burroughs TE, Graff R, Axelrod DA, Brennan DC, Lentine KL: Incremental value of the pancreas allograft to the survival of simultaneous pancreas-kidney transplant recipients. Diabetes Care 32:600-602, 2009

103. Morath C, Zeier M, Dohler B, Schmidt J, Nawroth PP, Opelz G: Metabolic control improves long-term renal allograft and patient survival in type 1 diabetes. J Am Soc Nephrol 19:1557-1563, 2008

104. Venstrom JM, McBride MA, Rother KI, Hirshberg B, Orchard TJ, Harlan DM: Survival after pancreas transplantation in patients with diabetes and preserved kidney function. JAMA 290:2817-2823, 2003

105. Kleinclauss F, Fauda M, Sutherland DE, Kleinclauss C, Gruessner RW, Matas AJ, Kasiske BL, Humar A, Kandaswamy R, Kaul S, Gruessner AC: Pancreas after living donor kidney transplants in 
diabetic patients: impact on long-term kidney graft function. Clin Transplant 23:437-446, 2009

106. Robertson RP, Sutherland DE, Kendall DM, Teuscher AU, Gruessner RW, Gruessner A: Metabolic characterization of long-term successful pancreas transplants in type I diabetes. J Investig Med 44:549-555, 1996

107. Fiorina P, La Rocca E, Venturini M, Minicucci F, Fermo I, Paroni R, D’Angelo A, Sblendido M, Di Carlo V, Cristallo M, Del Maschio A, Pozza G, Secchi A: Effects of kidney-pancreas transplantation on atherosclerotic risk factors and endothelial function in patients with uremia and type 1 diabetes. Diabetes 50:496-501, 2001

108. Luan FL, Miles CD, Cibrik DM, Ojo AO: Impact of simultaneous pancreas and kidney transplantation on cardiovascular risk factors in patients with type 1 diabetes mellitus. Transplantation 84:541-544, 2007

109. Fioretto P, Steffes MW, Sutherland DE, Goetz FC, Mauer M: Reversal of lesions of diabetic nephropathy after pancreas transplantation. N Engl J Med 339:69-75, 1998

110. Jukema JW, Smets YF, van der Pijl JW, Zwinderman AH, Vliegen HW, Ringers J, Reiber JH, Lemkes HH, van der Wall EE, de Fijter JW: Impact of simultaneous pancreas and kidney transplantation on progression of coronary atherosclerosis in patients with end-stage renal failure due to type 1 diabetes. Diabetes Care 25:906-911, 2002
111. Gross CR, Zehrer CL: Health-related quality of life outcomes of pancreas transplant recipients. Clin Transplant 6:165-171, 1992

112. Nathan DM, Fogel H, Norman D, Russell PS, Tolkoff-Rubin N, Delmonico FL, Auchincloss H Jr, Camuso J, Cosimi AB: Long-term metabolic and quality of life results with pancreatic/renal transplantation in insulin-dependent diabetes mellitus. Transplantation 52:85-91, 1991

113. Rao PS, Schaubel DE, Jia X, Li S, Port FK, Saran R: Survival on dialysis post-kidney transplant failure: results from the Scientific Registry of Transplant Recipients. Am J Kidney Dis 49:294-300, 2007

114. Ojo AO, Wolfe RA, Agodoa LY, Held PJ, Port FK, Leavey SF, Callard SE, Dickinson DM, Schmouder RL, Leichtman AB: Prognosis after primary renal transplant failure and the beneficial effects of repeat transplantation: multivariate analyses from the United States Renal Data System. Transplantation 66:1651-1659, 1998

115. Goldfarb-Rumyantzev AS, Hurdle JF, Baird BC, Stoddard G, Wang $\mathrm{Z}$, Scandling JD, Barenbaum LL, Cheung AK: The role of pre-emptive re-transplant in graft and recipient outcome. Nephrol Dial Transplant 21:1355-1364, 2006

116. Magee JC, Barr ML, Basadonna GP, Johnson MR, Mahadevan S, McBride MA, Schaubel DE, Leichtman AB: Repeat organ transplantation in the United States, 1996-2005. Am J Transplant 7:1424-1433, 2007 